\title{
Occurrence of human enterovirus in tropical fish and shellfish and their relationship with fecal indicator bacteria
}

\author{
Manjusha Lekshmi, Oishi Das, Sanath Kumar and Binaya Bhusan Nayak \\ Department of Post-Harvest Technology, Quality Control Laboratory, ICAR-Central Institute of Fisheries Education, \\ Versova, Mumbai, Maharashtra, India. \\ Corresponding author: Binaya Bhusan Nayak, e-mail: nayakbb@cife.edu.in \\ Co-authors: ML: manjusha@cife.edu.in, OD: oishi.phtpa505@cife.edu.in, SK: sanathkumar@cife.edu.in, \\ Received: 04-06-2017, Accepted: 27-07-2018, Published online: 18-09-2018
}

doi: 10.14202/vetworld.2018.1285-1290 How to cite this article: Lekshmi M, Das O, Kumar S, Nayak BB (2018) Occurrence of human enterovirus in tropical fish and shellfish and their relationship with fecal indicator bacteria, Veterinary World, 11(9): 1285-1290.

\begin{abstract}
Aim: Human enteroviruses in fish and shellfish are a health concern worldwide. Human infections occur due to the consumption of raw or insufficiently cooked fish or shellfish. The objective of this study was to determine the occurrence of human enteric viruses belonging to Enterovirus (EV) group in seafood in Mumbai and to correlate their occurrence with the bacterial indicators of fecal contamination.
\end{abstract}

Materials and Methods: Samples of fresh fish and shellfish collected from fish landing centers and retail fish markets were analyzed by virus concentration, nucleic acid extraction, and reverse transcription-polymerase chain reaction (RT-PCR). Bacterial indicators of fecal contamination were estimated by the most probable number technique. The relationship between the presence of virus and fecal indicators was determined by statistical analysis.

Results: A total of 89 samples comprising of fish, shrimps, oysters, clams, and mussels were screened in this study. EV was detected in $32(35.95 \%)$ samples, and all the virus-positive samples belonged to bivalve molluscan group. None of the finfish and crustacean shellfish samples was positive for the enteric viruses. Clams were found to be the most contaminated with $48.4 \%$ of the samples being positive for EV. The prevalence of enteric viruses in seafood samples showed a strong positive correlation with the bacteriological indicators of fecal contamination, suggesting that fecal coliform bacteria are good indicators of EVs in tropical seafood.

Conclusion: The presence of EVs in seafood is a public health hazard. Increasing level of coastal water contamination from anthropogenic sources is the primary reason for the contamination of seafood with EVs. Continuous monitoring of coastal waters and seafood for enteric viruses will help to ensure the safety of fish and shellfish for human consumption.

Keywords: coliforms, enterovirus, fish, indicator bacteria, reverse transcription-polymerase chain reaction, shellfish.

\section{Introduction}

Human enteric viruses are pathogens of public health significance responsible for food- and water-borne gastrointestinal diseases worldwide [1]. Infections are acquired through fecal route, with sewage and urban wastewater run-off being the major sources of contamination [2,3]. Enteric viruses are shed in extremely high numbers in the feces of infected individuals, typically between $10^{5}$ and $10^{11}$ virus particles per gram of stool [4]. Polioviruses $(\mathrm{PVs})$ and enteroviruses (EVs) are among the most common genera of the Picornaviridae family of enteric viruses that infect humans [5]. They are small, non-enveloped RNA viruses with a capsid of about 30-nm diameter and icosahedral symmetry [6]. The EV genome is comprised of a single-stranded

Copyright: Lekshmi, et al. Open Access. This article is distributed under the terms of the Creative Commons Attribution 4.0 International License (http://creativecommons.org/licenses/ by/4.0/), which permits unrestricted use, distribution, and reproduction in any medium, provided you give appropriate credit to the original author(s) and the source, provide a link to the Creative Commons license, and indicate if changes were made. The Creative Commons Public Domain Dedication waiver (http:// creativecommons.org/publicdomain/zero/1.0/) applies to the data made available in this article, unless otherwise stated. polyadenylated RNA of a positive sense of about 7500 bases with a single open reading frame (ORF) encoding a polyprotein with 2200 amino acids. The polyprotein ORF is flanked by a long untranslated region at the $5^{\prime}$ end (5'UTR) and a short UTR at the $3^{\prime}$ end [7]. A 22 amino acid virus-encoded protein is covalently linked to the $5^{\prime}$ end. These viruses are highly resistant to hostile environmental conditions such as high temperature, $\mathrm{pH}$, and radiation which facilitate their survival for long in the environment. Their small size, genome type, and non-enveloped capsid structure also play important roles in their survival [8].

Seafood such as shellfish are important vehicles of human enteric viruses [5]. Filter-feeding shellfish such as clams and oysters filter large volumes of water as part of their feeding activities and thus accumulate bacterial and viral pathogens [9]. Crustaceans such as crabs and shrimps acquire enteric viruses when they feed on contaminated oysters or other organisms and act as sources of transmission to humans [10]. Consumption of raw or partially cooked contaminated shellfish can lead to the transmission of disease. Many outbreaks have 
been reported due to the consumption of contaminated shellfish worldwide [11]. In general, enteric viral infections are mild and self-limiting. However, infections can occasionally lead to complications involving hepatitis, conjunctivitis, allergies, encephalitis, myocarditis, pericarditis, and foot and mouth disease $[12,13]$.

Despite their human health importance, studies on the prevalence of EVs in seafood from India are sparse $[9,14]$. Therefore, the present study was undertaken to investigate the prevalence of EVs in seafood samples from Mumbai and the relationship between their occurrence and bacteriological indicators of fecal contamination.

\section{Materials and Methods}

\section{Ethical approval}

Ethical approval was not required in this study since no live animals were used in the experiments.

\section{Sample collection and processing}

A total of 89 samples of fish and shellfish collected from fish landing centers, retail markets, and supermarkets were analyzed during the period from January 2016 to September 2017. The samples were collected in sterile plastic bags, transported to the laboratory in insulated ice boxes, and processed immediately. Live bivalve samples of clams, oysters and mussels were opened using a sterile shucking knife and the digestive glands were collected along with the intravalvular fluid. In the case of shrimps, hepatopancreas was dissected and collected, while muscle and skin from finfish samples were used for further processing.

\section{Concentration of virus}

The samples were subjected to the concentration process for viruses [15] before the extraction of viral nucleic acids. Briefly, samples of digestive glands, hepatopancreas, muscle, and skin were homogenized in a Stomacher (Seward Stomacher 80, Lab system, London, UK). The homogenate $(50 \mathrm{~g})$ was mixed with equal volume of glycine buffer $(0.5 \mathrm{M}$ glycine, $0.15 \mathrm{M} \mathrm{NaCl}, \mathrm{pH}$ 9.5), followed by magnetic agitation for $15 \mathrm{~min}$ at room temperature to release viruses from the tissue. The homogenate was clarified by centrifugation at $10,000 \times \mathrm{g}$ for $10 \mathrm{~min}$ at $4^{\circ} \mathrm{C}$. The supernatant was recovered, and an equal volume of $3 \%$ meat extract was added to precipitate and adsorb the viruses. After adjusting the $\mathrm{pH}$ to 3.5 , the supernatant was agitated for $30 \mathrm{~min}$ at room temperature and centrifuged at $10,000 \times \mathrm{g}$ for $15 \mathrm{~min}$ at $4^{\circ} \mathrm{C}$. The pellet was resuspended in $5 \mathrm{~mL}$ of phosphate-buffered saline (PBS) (pH 7). The extract was precipitated with 50\% PEG 6000 and added in a ratio of 1:4 (v/v). The $\mathrm{pH}$ was adjusted to 7.2 , and the solution was incubated overnight at $4^{\circ} \mathrm{C}$. The precipitate was clarified by centrifugation at $10,000 \times g$ at $4{ }^{\circ} \mathrm{C}$ for $45 \mathrm{~min}$. The pellets were resuspended in $5 \mathrm{~mL}$ PBS ( $\mathrm{pH} 7$ ), aliquoted, and stored at $-20^{\circ} \mathrm{C}$.
RNA extraction and CDNA synthesis from viral concentrate

Total RNA was extracted from the concentrated samples using the SV Total RNA Isolation Kit (Promega, USA) according to the manufacturer's protocol. The extracted RNA was converted into cDNA using GoScript Reverse Transcription System (Promega, USA). Polymerase chain reaction (PCR) was performed on the cDNA template using virus group-specific primers.

\section{Detection of EV by PCR}

For the detection of EV group, nested PCR primers ENV-F (CAAGCACTTCTGTTTCCCCGG), ENVR1 (ATTGTCACCATAAGCAGCCA) and ENV-R2 (CTTGCGCGTTACGAC) were used [16]. cDNA $(3 \mu \mathrm{L})$ was subjected to PCR amplification in a $30 \mu \mathrm{L}$ volume comprising of $15 \mu \mathrm{L}$ of EmeraldAmp PCR 2X Master Mix (TaKaRa, Japan) and 30 picomoles of forward and reverse primers. In the case of nested PCR, $3 \mu \mathrm{L}$ of the first step PCR product was used as the template DNA for the second round of amplification. All amplifications were done in a SimpliAmp Thermal Cycler (Thermo Fisher Scientific, USA). The PCR products were analyzed by electrophoresis on $2.0 \%$ agarose gels, stained with ethidium bromide $(0.5 \mu \mathrm{g} / \mathrm{mL})$, and photographed using a gel documentation system (Bio-Rad, USA). A 435 bp cloned fragment of EV was used as the positive control in PCR assays.

\section{Determination of fecal coliform count by most prob- able number (MPN) technique}

Fecal coliform and Escherichia coli counts were determined in all the samples of fish and shellfish following conventional method [17]. Briefly, a $25 \mathrm{~g}$ of the seafood sample was homogenized in $225 \mathrm{~mL}$ of Butterfield's phosphate-buffered water for $2 \mathrm{~min}$. Appropriate 10-fold dilutions of the homogenate were prepared and inoculated into lauryl sulfate tryptose broth tubes (3-tube MPN) and incubated at $37^{\circ} \mathrm{C}$ for $24-48 \mathrm{~h}$. Two loopfuls from positive tubes, indicated by turbidity and gas production, were inoculated into $E$. coli broth and incubated at $44.5^{\circ} \mathrm{C}$ for $24-48$ h. E. coli was isolated from positive tubes on eosin methylene blue agar plates and typical colonies of $E$. coli were identified by indole, methyl red, Voges-Proskauer and citrate tests.

\section{Statistical analysis}

Association between EV-positive samples and the bacteriological indicators of fecal contamination was determined using SPSS version 15.0 (SPSS Inc., Chicago, IL, USA). The values of fecal coliform counts and number of E. coli were converted to logarithmic forms, and the correlation coefficient was estimated. Association was analyzed using Pearson's Chi-squared test. Results with $\mathrm{p}<0.05$ were considered as statistically significant.

\section{Results}

\section{Prevalence of EV in seafood}

The EV-specific first step primers ENV-F and ENV-R1 yielded a 435 bp amplification product with 
virus-positive samples (Figure-1). Some samples of shellfish, which were negative in the first step, showed positive amplification of $362 \mathrm{bp}$ with nested primers ENV-F and ENV-R2 (Figure-2). Of 89 seafood samples analyzed by reverse transcription-PCR (RT-PCR), EV RNA was detected in 32 samples with a prevalence of $35.95 \%$ (Table-1). Only bivalve shellfish samples were positive for the presence of EV by PCR, while none of the crustacean shellfish and finfish samples was positive for the presence of these viruses (Table-1). The prevalence was found to be highest in black clams with $48.4 \%$ of samples being positive for EV. Of 16 samples of oysters analyzed, EV was detected in 9 samples, while 6 of the 19 samples of Asiatic hard clams tested positive for the viral RNA (Table-1). Enterovirus RNA was also detected in one sample each of green mussel and marsh clam (Table1). Among the samples tested, enteroviruses were predominantly detected in samples collected from open and retail markets of Mumbai.

\section{Relationship between EV detection and fecal indica- tor bacteria}

All $(100 \%)$ the samples analyzed in this study were positive for fecal coliforms by MPN method (Table-2). The samples positive for enteroviruses were analyzed further for correlation with the fecal coliform load (Table-2). Among the samples positive for EV,

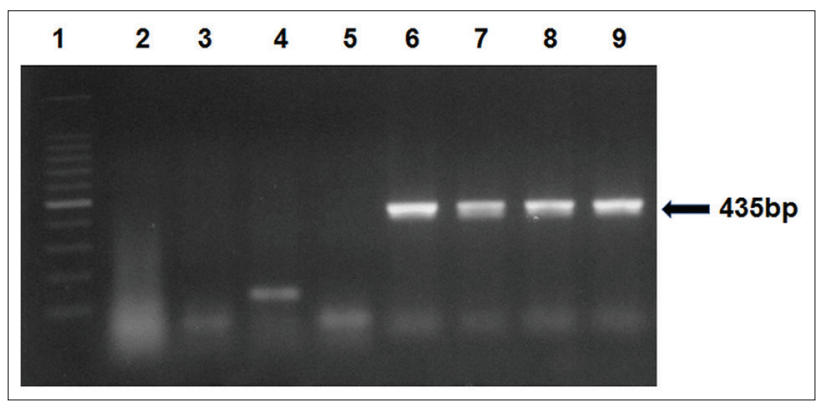

Figure-1: Detection of enterovirus (EV) RNA by reversetranscriptase PCR using primers ENV-F and ENV-R1. Lane 1: 100 bp DNA ladder, Lane 2: Negative control, Lanes 3-5: EV-negative samples, Lane 6: Meretrix meretrix, Lane 7: Perna viridis, Lane 8: Villorita cyprinoides, Lane 9: Positive control.

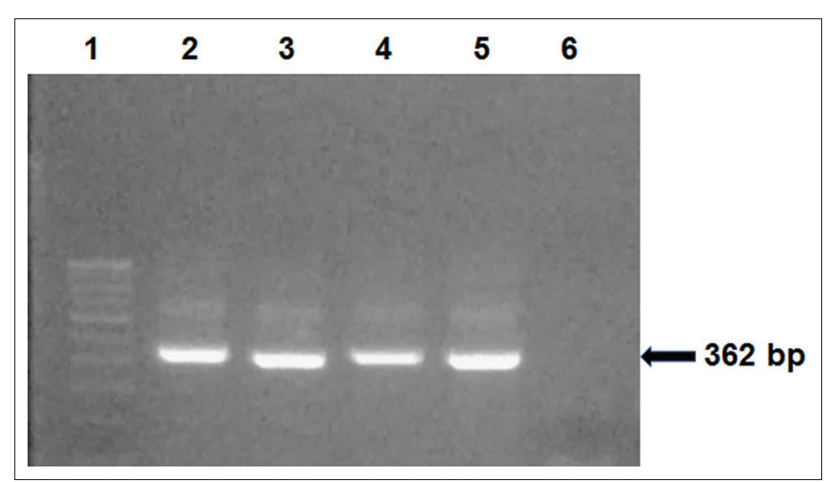

Figure-2: Amplification of enterovirus nucleic acid using nested primers ENV-F and ENV-R2. Lane 1: 100 bp DNA ladder, Lane 2: Positive control, Lanes 3 and 4: Saccostrea cucullata, Lane 5: Meretrix meretrix, Lane 6: Negative control.
$52.17 \%$ of the samples harbored fecal coliforms ranging in counts from 20 to $100 \mathrm{MPN} / 100 \mathrm{~g}$ of the sample, while $37.84 \%$ and $8 \%$ of the samples harbored fecal coliforms counts of $<20$ and $>100$ MPN/100 g, respectively (Table-2). However, majority of the samples showed E. coli counts of $<4$ MPN/100 g of the sample, while $25.92 \%$ and $16.6 \%$ of the samples showed $E$. coli loads of 4-8 and $>8$ MPN per $100 \mathrm{~g}$ of the sample, respectively (Table-2).

Statistical analysis revealed a significant positive correlation (0.839) between fecal coliforms and the presence of enterovirus in samples. Correlation between E. coli isolation and detection of enterovirus was found to be positive and significant (0.813) (Table-2).

\section{Discussion}

Enteric viruses are an important group of organisms responsible for causing gastrointestinal infections in humans. Several outbreaks of enteric viral infections linked to contaminated shellfish, especially bivalves, have been reported globally $[18,19]$. The present study was aimed to determine the prevalence of EV in seafood from Mumbai, India. The samples included seafood intended for human consumption such as shellfish (oysters, clams, mussels, and shrimps) and finfish (sardine, mackerel, anchovy etc.). The coastal water off Mumbai, especially the creeks, is prone to fecal contamination through the discharge of sewage and anthropogenic activities by human settlement close to the coastal water. Shellfish harboring EV were either directly harvested from such contaminated waters or might have got contaminated with EV during various stages of handling and transportation. The results of this study also hold significance in view of the very limited studies on the occurrence of enteric viruses in seafood in India. Umesha et al. [9] reported the occurrence of EVs in $37 \%$ of oyster, $46 \%$ of clam, and $15 \%$ of shrimp samples and adenovirus in $17 \%$ of oyster and $27 \%$ of clam samples collected from the south-west coast of India. In our study, $48.4 \%$ of the clam samples were positive for EVs, with an overall prevalence of $35.9 \%$ of EVs among all the samples screened. Le Guyader et al. [20] reported that 21\% of oyster samples and $45 \%$ of mussel samples were contaminated with EVs along with other enteric viruses during a 3-year study. In a study by Mesquita et al. [21] in Portugal, EVs were detected in 35\% of the shellfish analyzed. EVs were detected in $43.9 \%$ of bivalve mollusks screened from the northwestern coast of Spain [22].

The high prevalence of EV in bivalves such as clams and oysters can be attributed to their filter feeding habit which enables them to accumulate enteric viruses from the surrounding water [13]. The presence of enteric viruses in bivalves collected from fish landing centers and retail supermarkets indicates that they are marketed without adequate depuration process to remove these pathogens. Although sewage treatment 
Table-1: Occurrence of EV in different samples analyzed in this study.

\begin{tabular}{|c|c|c|c|}
\hline Sample & Scientific name & Number of samples analyzed & Number positive for EV* \\
\hline \multicolumn{4}{|l|}{ Bivalves } \\
\hline Black clam & Villorita cyprinoides & 31 & 15 \\
\hline Rock oyster & Saccostrea cucullata & 10 & 7 \\
\hline Cupped oyster & Crassostrea gryphoides & 6 & 2 \\
\hline Asiatic hard clam & Meretrix meretrix & 19 & 6 \\
\hline Green mussel & Perna viridis & 2 & 1 \\
\hline Marsh clam & Polymesoda erosa & 1 & 1 \\
\hline \multicolumn{4}{|l|}{ Crustaceans } \\
\hline Indian white prawn & Penaeus indicus & 2 & 0 \\
\hline Speckled shrimp & Metapenaeus monoceros & 8 & 0 \\
\hline Paste shrimp & Acetes spp. & 3 & 0 \\
\hline \multicolumn{4}{|l|}{ Finfish } \\
\hline Indian anchovy & Stolephorus indicus & 2 & 0 \\
\hline Oil sardine & Sardinella longiceps & 3 & 0 \\
\hline Indian Mackerel & Rastrelliger kanagurta & 2 & 0 \\
\hline Total & & 89 & $32(35.95)$ \\
\hline
\end{tabular}

*Based on the detection of viral nucleic acid. $\mathrm{EV}=$ Enterovirus

Table-2: Relationship between fecal coliform load and the incidence of enteric viruses in seafood samples.

\begin{tabular}{lccc}
\hline Fecal coliform count & Number of samples tested & Number $(\%)$ positive for EV* $\mathbf{r}$ value (correlation coefficient) \\
\hline$<20$ & 37 & $14(37.8)$ & 0.839 \\
$20-100$ & 23 & $12(52.1)$ \\
$>100$ & 25 & $2(8)$ & 0.813 \\
E. coli count & & $15(68.1)$ \\
$<4$ & 22 & $7(25.9)$ \\
$4-8$ & 27 & $6(16.6)$ & \\
$>8$ & 36 &
\end{tabular}

*Based on the detection of viral nucleic acid. $\mathrm{EV}=$ Enterovirus, $E$. coli=Escherichia coli

processes have improved, still large volumes of sewage enter into the coastal waters leading to the contamination of shellfish in the region of this study. Individuals who consume such contaminated shellfish are at risk of gastrointestinal infections. Several reports have been published describing the outbreak of acute gastroenteritis from enteric viruses in humans related to consumption of seafood, especially bivalve shellfish globally [23]. Foodborne gastroenteritis outbreak due to enteric viruses is substantially underreported in India due to inadequate facilities for source tracking and lack of research efforts in this field.

Currently, fecal coliforms and E. coli are used as indicators of fecal contamination of food and water. Indicator bacteria are very useful for monitoring the contamination status of coastal water and the seafood. However, studies suggest that fecal indicator bacteria are not reliable indicators of the presence of enteric viruses $[9,24]$. The low levels of correlation between fecal indicators and enteric viruses have further consolidated this hypothesis. The reason for low correlation has been attributed to slow depuration rate of enteric viruses compared to the pathogenic bacteria. This may be true when the level of fecal contamination is very low, which provides ample scope for natural depuration. We observed a positive correlation between fecal indicator bacteria and the presence of EVs (Table-2). The correlation values strongly suggest an association between the presence of enteroviruses and the bacteriological quality evaluated. This observation is in accordance with Moreno et al. [23], although it is contradictory to the observations of few others [9,21]. One possible factor affecting the high correlation could be different microbial densities in the original contamination sources [24]. The presence of enteroviruses in the samples studied strongly suggests high levels of fecal pollution in the area of sampling in this study. The high correlation between $\mathrm{EV}$, fecal coliforms, and $E$. coli may be attributed to this persistent and perhaps, recent fecal contamination of seafood. However, the use of fecal coliforms or E. coli as indicators of $\mathrm{EV}$ in shellfish needs to be cautiously analyzed. Our results suggest that $52.17 \%$ of the samples positive for EV harbored median level (20-100 MPN/100 g) fecal coliform counts (Table-2), while $68.18 \%$ of the samples with $E$. coli counts of $<4$ MPN/100 g were positive for EV (Table-2). A study on coastal seawater samples from Santa Monica Bay, CA over a 6-year period showed no significant correlation between the presence of EVs and total coliforms, fecal coliforms, or enterococci [25]. It may be worthwhile to explore alternate indicators of EV presence in seafood and coastal waters. Recent studies have shown the utility of human-specific coliphages as good indicators of human viral pathogens [26].

\section{Conclusion}

Our study suggests the contamination of seafood and shellfish in particular, harvested and sold 
off Mumbai coast with EVs. Virus concentration followed by RT-PCR could be successfully used to detect the presence of EVs in seafood. Cell culture assays take weeks to months to perform and are not suitable for regular monitoring of food and water samples [27]. Moreover, there is no single cell line that allows the propagation of diverse EV species. RT-PCR assay is widely followed for the detection of enteric viruses in fish and shellfish samples and is considered reliable for routine monitoring of samples. Further studies are necessary to determine the prevalence of different groups of enteric viruses in seafood and the critical points of contamination and to establish an effective indicator of viral contamination for tropical seafood.

\section{Authors' Contributions}

BBN conceived and designed the experiments; ML performed the experiments. OD assisted in sampling and molecular analysis; $\mathrm{BBN}, \mathrm{SK}$, and $\mathrm{ML}$ planned the experiments and analyzed the data. All authors read and approved the final manuscript.

\section{Acknowledgments}

The authors are grateful to the Director, ICARCentral Institute of Fisheries Education, for the help and advice. This research is part of the institutional (ICAR-Central Institute of Fisheries Education, Maharashtra, India) project CIFE-2013/4.

\section{Competing Interests} interests.

The authors declare that they have no competing

\section{References}

1. Richards, G.P. (2016) Shellfish-associated enteric virus illness: Virus localization, disease outbreaks and prevention. In: Goyal, S., Cannon, J., editors. Viruses in Foods. Food Microbiology and Food Safety. Springer, Cham.

2. Connell, C., Tong, H.I., Wang, Z., Allmann, E. and Lu, Y. (2012) New approaches for enhanced detection of enteroviruses from Hawaiian environmental waters. PLoS One, 7: 1-9.

3. Kotwal, G. and Cannon, J.L. (2014) Environmental persistence and transfer of enteric viruses. Curr. Opin. Virol., 4: 37-43.

4. Hellmér, M., Paxéus, N., Magnius, L., Enache, L., Arnholm, B., Johansson, A., Bergström, T. and Norder, H. (2014) Detection of pathogenic viruses in sewage provided early warnings of hepatitis A virus and norovirus outbreaks. Appl. Environ. Microbiol., 80: 6771-6781.

5. Greening, G.E. and Cannon, J.L. (2016) Human and animal viruses in food (including taxonomy of enteric viruses). In: Goyal, S., Cannon, J., editors. Viruses in Foods. Food Microbiology and Food Safety. Springer, Cham.

6. Huang, W., Wang, G., Zhuge, J., Nolan, S.M., Dimitrova, N. and Fallon, J.T. (2015) Whole-genome sequence analysis reveals the enterovirus D68 isolates during the United States 2014 outbreak mainly belong to a novel clade. Sci. Rep., 5: 15223.

7. Piralla, A., Daleno, C., Scala, A., Greenberg, D., Usonis, V., Principi, N., Baldanti, F. and Esposito, S. (2013) Genome characterisation of enteroviruses 117 and 118: A new group within human enterovirus species C. PLoS One, 8: e60641.

8. Hassard, F., Gwyther, C.L., Farkas, K., Andrews, A., Jones, V., Cox, B., Brett, H., Jones, D.L., McDonald, J.E. and Malham, S.K. (2016) Abundance and distribution of enteric bacteria and viruses in coastal and estuarine sediments-a review. Front Microbiol., 7: 1692.

9. Umesha, K.R., Bhavani, N.C., Venugopal, M.N., Karunasagar, I., Krohne, G. and Karunasagar, I. (2008) Prevalence of human pathogenic enteric viruses in bivalve molluscan shellfish and cultured shrimp in South West coast of India. Int. J. Food Microbiol., 122: 279-286.

10. Suffredini, E., Corrain, C., Arcangeli, G., Fasolato, L., Manfrin, A., Rossetti, E., Biazzi, E., Mioni, R., Pavoni, E., Losio, M.N., Sanavio, G. and Croci, L. (2008) Occurrence of enteric viruses in shellfish and relation to climatic-environmental factors. Lett. Appl. Microbiol., 47: 467-474.

11. McLeod, C., Polo, D., Le Saux, J. and Le Guyader, F.S. (2017) Depuration and relaying: A review on potential removal of norovirus from oysters. Comp. Rev. Food Sci. Food Saf., 16: 692-706.

12. Muehlenbachs, A., Bhatnagar, J. and Zaki, S.R. (2015) Tissue tropism, pathology and pathogenesis of enterovirus infection. J. Pathol., 235: 217-228.

13. Mohan, V., Rawat, S., Lokesh, K.M., Mohan, H.V., Reddy, D.A., Kumar, A. and Bhilegaonkar, K.N. (2014) Prevalence of rotavirus in shellfish from Southern Kerala. Vet. World, 7: 821-824.

14. Anbazhagi, S. and Kamatchiammal, S. (2010)Contamination of seafood by norovirus in India. Int. J. Virol., 6: 138-149.

15. Le Guyader, F., Dubois, E., Menard, D. and Pommepuy, M. (1994) Detection of hepatitis A virus, rotavirus, and enterovirus in naturally contaminated shellfish and sediment by reverse transcription-semi-nested PCR. Appl. Environ. Microbiol., 60: 3665-3671.

16. Leparc, I., Aymard, M. and Fuchs, F. (1994) Acute, chronic and persistent enterovirus and poliovirus infections: Detection of viral genome by semi-nested PCR amplification in culture-negative samples. Mol. Cell Probes., 8(6): 487-495.

17. FDA. (2004) Bacteriological Analytical Manual. US Food and Drug Administration Center for Food Safety, Washington, DC.

18. Thebault, A., Teunis, P.F.M., Le Pendu, J., Le Guyader, F.S. and Denis, J.B. (2013) Infectivity of GI and GII noroviruses established from oyster related outbreaks. Epidemics, 5: 98-110.

19. Bellou, M., Kokkinos, P. and Vantarakis, A. (2013) Shellfish-borne viral outbreaks: A systematic review. Food Environ. Virol., 5: 13-23.

20. Le Guyader, F., Haugarreau, L., Miossec, L., Dubois, E. and Pommepuy, M. (2000) Three-year study to assess human enteric viruses in shellfish. Appl. Environ. Microbiol., 66: 3241-3248.

21. Mesquita, J.R., Vaz, J., Cerqueira, S., Castilho, F., Santos, R., Monteiro, S., Manso, F.C., Romalde, J.L. and Nascimento, M.S.J. (2011) Norovirus, hepatitis A virus and enterovirus presence in shellfish from high-quality harvesting areas in Portugal. Food Microbiol., 28: 936-941.

22. Romalde, J.L., Area, E., Sa'nchez, G., Ribao, C., Torrado, I., Abad, X., Pinto, R.M., Barja, J.L. and Bosch, A. (2002) Prevalence of enterovirus and hepatitis A virus in bivalve molluscs from Galicia (NW Spain): Inadequacy of the EU standards of microbiological quality. Int. J. Food Microbiol., 74: 119-130

23. Moreno, E., Espigares, E., Marañón, M., Ma Ochoa, L., Espigares, M. and Fernández-Crehuet, M. (2014) The prevalence of noroviruses in bivalve molluscs sold in Granada (Spain) fish markets. Molluscan Res., 34: 176-180.

24. Azzouzi, L.M.I., Senouci, S., Qazoui, M.E., Oumzil, H. and Naciri, M. (2017) Detection of enterovirus in mussels from Morocco by cell culture and real-time PCR. Afr. J. Biotechnol., 16: 1791-1799.

25. Noble, R.T. and Fuhrman J.A. (2001) Enteroviruses detected by reverse transcriptase polymerase chain reaction from the coastal waters of Santa Monica Bay, California: Low 
correlation to bacterial indicator levels. Hydrobiologia, 460: $175-184$.

26. Vergara, G.G.R., Goh, S.G., Rezaeinejad, S., Chang, S.Y., Sobsey, M.D. and Gin, K.Y.H. (2015) Evaluation of FRNA coliphages as indicators of human enteric viruses in a tropical urban freshwater catchment. Water Res., 79: 39-47.

27. Fong, T.T. and Lipp, E.K. (2005) Enteric viruses of humans and animals in aquatic environments: Health risks, detection, and potential water quality assessment tools. Microbiol. Mol. Biol. Rev., 69(2): 357-371.

$* * * * * * * *$ 